\title{
Topkapı Sarayı Bağdat Köşkü Çinileri
}

\author{
Topkapı Palace Baghdad Kiosk Tiles
}

\section{E. Emine Naza Dönmez* (i)}

Öz

Topkapı Sarayı dördüncü avluda yer alan Bağdat Köşkü, Sarayın en güzel manzarasını seyreder. IV. Murad tarafından (16121640) 1639 yılında ikinci Bağdat seferinin anısına yapılmıştır. Mimarı hassa baş mimarı Kasım Ağa olmalıdır. Yapının dış cephelerinde alt pencerelerin üstü çinilerle donatılmıştır. İçinde ise pandantifler, eyvan kemerleri, pencere araları ve dolap içleri çini kaplıdır. Mekânda ocağın iki yanında ve pencere aralarında yer alan kuş ve kilin figürlerinin de bulunduğu panolar saz üslubundadır. Bu panolar Topkapı Sarayı Sünnet Odası (1640) cephesinde yer alan 16. yüzyıl örneklerinin 17. yüzyılda yapılmış başarılı birer kopyasıdır. Topkapı Sarayı Bağdat Köşkü’nde yer alan celi sülüs hatlı Ayetel Kürsi'yi, Tophaneli Enderuni Mahmud Çelebi’nin yazdığı bilinmektedir. Yapıdaki çiniler sır altı tekniğinde mavi-beyaz renklidir. Çini üretiminin çok yoğun yaşandığı 17. yüzyılda Kütahya ve İznik atölyeleri birlikte üretim yapmaya devam etmiştir. Topkapı Sarayı Bağdat Köşkü dış cephe çinileri boyut ve desenleri anlamında Kütahya gibi durmaktadır. İç mekân çinilerinin ise aynı sebebe dayanarak İznik üretimi olduğu düşünülmektedir.

\section{Anahtar Kelimeler}

Bağdad Köşkü, Çini, İznik, Kütahya, 17.yüzyıl

\begin{abstract}
Baghdad Kiosk, which is located in the fourth court of Topkapı Palace, overlooks the most beautiful view of the palace. It was built by Murad IV (1612-1640) to commemorate the Baghdad Campaign in 1639. It's architect was most likely civil chief-architect Kasım Aga. Tiles adorn the upper parts of the lower windows on the exterior. The interior pendetives, iwan arches, spaces between the windows and insides of the cabinets were also tiled. Panels situated on both sides of the fireplace and between the windows decorated with bird and kilin figures are in the reed style. These panels are successful $17^{\text {th }}$ century copies of the $16^{\text {th }}$ century examples from the Topkapı Palace Circumcision Chamber (1640) facade tiles. It is known that the Ayetel Kürsi of celi sülüs calligraphy in the Topkapı Palace Baghdad Kiosk belonged to Enderuni Mahmud Çelebi of Tophane. Technically and artistically, the tiles in the structure were produced using the underglaze technique and are blue and white in color. In the $17^{\text {th }}$ century, when tile production was very intense, the Kütahya and Iznik workshops continued their production together. Topkapı Palace Baghdad Pavilion's exterior tiles resemble those of Kütahya in terms of size and patterns. The interior tiles are thought to be produced by İznik for the same reason.
\end{abstract}

\section{Keywords}

Baghdad Kiosk,Tile, İznik, Kütahya, $17^{\text {th }}$ century

* Sorumlu Yazar: E. Emine Naza Dönmez (Doç. Dr.), İstanbul Üniversitesi, Edebiyat Fakültesi, Sanat Tarihi Bölümü, İstanbul, Türkiye. E-posta: edonmez@istanbul.edu.tr ORCID: 0000-0002-7130-113X

Attf: Naza Dönmez, E. Emine. "Topkapı Sarayı Bağdat Köşkü Çinileri.” Art-Sanat, 15(2021): 203-227. https://doi.org/10.26650/artsanat.2021.15.0009 


\section{Extended Summary}

The Baghdad Kiosk, which is located in the fourth court of Topkap1 Palace, overlooks the most beautiful view of the palace. It was built by Murad IV (1612-1640) to commemorate the Baghdad Campaign in 1639. It's architect was most likely civil chief-architect Kasim Aga. It is a structure with a central dome and four iwans. There is a cloister surrounding the windowed structure from the outside. Tiles adorn the upper parts of the lower windows on the exterior. The interior pendetives, iwan arches, spaces between the windows and insides of the cabinets were also tiled. Panels situated on the both sides of the fireplace and between the windows decorated with bird and kilin figures are in the reed style. Nakkaşbaş1 Şah Kulu is the person who started this style at the Palace. This decoration style started in the mid- $16^{\text {th }}$ century and was generally used in other art forms and was seen in tile, illumination, fabric, binding, hand-srawing decorations and was seen in lacquer art in the $18^{\text {th }}$ century. The panels in question are successful $17^{\text {th }}$ century copies of the $16^{\text {th }}$ century examples from the Topkap1 Palace Circumcision Chamber (1640) facade tiles. The reed style in $17^{\text {th }}$ century tile decoration can be seen in two buildings. These are the Topkap1 Palace Baghdad Pavillion and the Cairo Aksungur Mosque. The panels in the Topkap1 Palace Baghdad Pavilion are large reed leaves and hatayis coming out of the vase on both sides of the hearth. Bird figures are also seen among them. One of the panels on the walls is a panel of clay. This work is also one of the successful examples of the reed style. This same decoration is seen on the altars of the Aksungur Mosque in Cairo. Here too, the reed leaves coming out of the vase form the decoration. These panels are located on the facade of the Topkapı Palace Circumcision Room. It is a successful copy made in the 17th century. These decorations in the reed style in question are seen as Ottoman imitations on the Stroganoff Palace of Rome's tiles in Italy. It is known that the Ayetel Kürsi of celi sülüs calligraphy in Topkapı Palace Baghdad Kiosk belonged to Enderuni Mahmud Çelebi of Tophane. Technically and artistically, the Topkapı Palace Baghdad Kiosk is the most prominent structure adorned with Ottoman tile art of the $17^{\text {th }}$ century. It is also noteworthy for the successful other than the value of the adornments, it is also noteworthy for the successful application of tiles. Other than the tile calligraphy, the panels adorning the insides of the arches and the interior of the structure in reed technique were designed according the locations they were placed. The tiles in the structure were produced using the underglaze technique and were blue and white in color. The blue and white color creates harmony in a structure in which the tiles were used so extensively, creating a peaceful environment. While this condition is true for the Topkapı Palace Revan Kiosk (1635), Topkapı Palace Baghdad Kiosk, Üsküdar Tiled Mosque (1640) and the complex of Yeni Cami (1663), the blue and white color palette is also preferred in the tiles covering the entire structure, constructed in the second half of $17^{\text {th }}$ century. In the $17^{\text {th }}$ century, when the tile production was very intense, Kütahya and İznik workshops continued their production together. In this case, 
especially in the Topkapı Palace Harem, İznik and Kütahya tiles were used together in many buildings where tile decoration was applied. Apart from the few archive sources, it is possible to partially distinguish the production places of the tiles of the buildings in question from the selection of sizes and patterns. The Topkap1 Palace Baghdad Pavilion's exterior tiles resemble Kütahya in terms of size and patterns. The interior tiles are thought to be produced by İznik for the same reason. Based on the structures built in the $17^{\text {th }}$ century, it is understood that there was an intense tile activity in this period. It is known that although ceramics export to Europe stopped in the $17^{\text {th }}$ century, tile exports continued intensively. These tiles were uncovered in the structure known as the Red Tower in the Transylvanian Saropatlak Castle excavations in Europe. However, these tiles are different than the $17^{\text {th }}$ century tiles. In addition to the monastery in Mount Athos, Greece, a small number of $17^{\text {th }}$ century Turkish tile pieces were found in the castles in Moldavia Suceava and Iaşi. The Iznik tiles in the Mount Athos monastery are examples of naturalist flower decorated skirting tiles coming out of a pedestal bowl. Another structure mentioned in the correspondence from this period is the Crimean Khan Palace tiles. These tiles are also $17^{\text {th }}$ century Turkish tiles. It is clear that not all of these are made in Iznik. Most of Iznik tile workshops remained unused after the construction of the Sultan Ahmed Mosque. Evliya Çelebi mentions more than three hundred workshops during the reign of Sultan Ahmed I (1603-1617), in which nine were open in Iznik by 1648.Therefore, in the exports and domestics market Kütahya became a second center. As it was seen in some examples, it is thought that the tiles that do not resemble both centers may have been made in Istanbul workshops.

Iznik is one of the centers of the Ottoman Empire's tile and ceramic production. The ceramic pots it produces are world famous. Also, Iznik tiles constitute the vast majority of the tiles that adorn the Ottoman buildings of the $17^{\text {th }}$ century. Kütahya has been a center of tile and ceramics since the Principalities Period. Kütahya is seen as the second center after Iznik in the Ottoman Period. Especially, at the end of the $16^{\text {th }}$ century and the at the beginning of the $17^{\text {th }}$ century, Iznik and Kütahya were producing under equal conditions and designs. Kütahya remained in the background with the rise of Iznik tiles in $16^{\text {th }}$ century. Undoubtedly, Kütahya continued its activities in this period as well. It is known that production in Kütahya was greater than İznik in the $17^{\text {th }}$ century.

Kütahya and İznik workshops continued to produce together in the $17^{\text {th }}$ century when the tile production was very intense. In this case, Iznik and Kütahya tiles were used together in the Sultan Ahmet Mosque, Üsküdar Tiled Mosque and New Mosque and especially in the Topkapı Palace Harem where tile decoration was used. Apart from the few archive sources, it is possible to partially distinguish the production places of the tiles of the buildings in question from the selection of sizes and patterns. The façade tiles of the Topkapı Palace Baghdad Pavilion look like Kütahya in terms of size and patterns. The interior tiles are thought to be produced by Iznik for the same reason. 


\section{Giriş}

Topkapı Sarayı dördüncü avlusunda yer alan Bağdat Köşkü IV. Murad tarafindan (1612-1640) 1639 yılında ikinci Bağdat seferinin anısına yapılmıştır. Mimarı hassa baş mimarı Kasım Ağa olmalıdır. Topkapı Sarayı'nın yapıldığı şekli ile günümüze ulaşan Bağdat Köşkü Türk köşk mimarisinin en güzel örneklerindendir. Yapı Topkap1 Sarayı IV. avlusunda Havuzlu taşlığın bir kenarında Şimşirlik ve İncirlik denilen iki bahçenin birleştiği yerde $7 \mathrm{~m}$. yüksekliğinde kemerli bir bodrum katı üstüne oturtulmuştur. Bulunduğu yerden Haliç, Boğaz ve Marmara’ya hâkim manzarası olduğu gibi Galata ve Beyoğlu'nu da bütünüyle görmektedir². Merkezi kubbeli, dört eyvanlı bir yapıdır. Dışarıda yapıyı çevreleyen bir revak yer alır. İki sıra pencereli yapı Revan Köşkü (1635)'nün daha büyük ölçekte yapılmış şeklidir. Köşkün etrafını kurşun kaplı ahşap saçaklı bir revak çevreler. İki renkli mermerden sivri kemerli bu revakı yirmi iki mermer sütun taşır. Havuzlu taşlığa açılan ana giriş dışında revakların arası mermer korkulukludur. Yapıyı çevreleyen iki sıralı pencereler otuz iki adettir. Yapının üç kapısı bulunmaktadır. Ana giriş kapısının üzerindeki Farsça beyitte "Devlette iken bu yer hep açık olsun. Hakklyla eşhedü en la ilahe illallah" yazılıdır³. Bu kapının söve ve kemerleri beyaz ve yeşil, diğer kapıların ise beyaz mermerdir. Merkezi kubbeli yapının kubbesinin ortasında bir aydınlık feneri bulunur. Kubbe kurşun kaplıdır. Simetrik kuruluşlu köşkün ana giriş kapısının karşısında altın yaldızlı davlumbazlı bir ocak bulunur. Ocağın çatıda ince uzun bir bacası görülür. Bu ocağın yaslandığı duvarın arka tarafına dikdörtgen planlı ve üstü aynalı tonoz ile örtülü bir oda eklenmiştir. $\mathrm{Bu}$ odanın duvar kalınlığı içine ustalıkla yerleştirilmiş bir tuvalet bulunur. Köşkün içinde ahşap eyvan tavanlar altın yaldızlı bir tezyinat ile kaplıdır. Kubbe altın yaldızlı ve malakari süslemelidir. Dıştan pirinç şebekeli olan alt sıra pencerelerin ve dolapların ahşap kanatları fildişi, sedef ve bağa kakma süslemelidir. Üst sıra pencereler renkli camlı, alçı çerçeveli revzenlere sahiptir ${ }^{4}$ (G. 1).

1 Sedat Hakkı Eldem, Köşkler ve Kasırlar I (İstanbul: Devlet Güzel Sanatlar Akademisi, 1968), 298-318; Sedat Hakkı Eldem ve Ferudun Akkozan, Topkapı Sarayı (İstanbul, Kültür ve Turizm Bakanlığı Yayınları, 1982), 28-29; Semavi Eyice, "Bağdat Köşkü,” Dünden Bugüne İstanbul Ansiklopedisi, c. 1 (İstanbul: Tarih Vakfi, 1993), 531-532; Semavi Eyice, "Kasım Ağa," TDV İslam Ansiklopedisi, c. 24 (İstanbul: Türkiye Diyanet Vakfı Yayınları, 2001), 539-540; Muharrem Orhan Bayrak, Topkapı Sarayı (İstanbul: Sümer Kitapevi Yayınları, 1996), 59-60: E. Emine Naza Dönmez, "Türk Çini Sanatının Sürekliliği İçinde XVII. Yüzyıl Eserlerinin Yeri”" (Yayınlanmamış Doktora Tezi, İstanbul Üniversitesi, 2001), 9; E. Emine Naza Dönmez, "Osmanlı Dönemi Türk Çini Sanatı (Erken, Klasik, Geç Devirler)," Türkler Ansiklopedisi, c. 12 (Ankara: Yeni Türkiye Yayınları, 2002), 366-375; Belgin Demirsar Arlı ve Ara Altun, Anadolu Toprağının Hazinesi Çini Osmanlı Dönemi (İstanbul: Kale Grubu Kültür Yayınları, 2008), 125; Funda Koçer Yeşilyurt, “Topkapı Sarayı Dördüncü Avludaki Yapılarda Kullanılan Çiniler”" (Doktora Tezi, Atatürk Üniversitesi, 2014), 183.

2 Eyice, "Bağdat Köşkü," 531-532.

3 Eldem ve Akkozan, Topkapı Sarayl, 28.

4 Eyice, "Bağdat Köşkü," 531-532. 


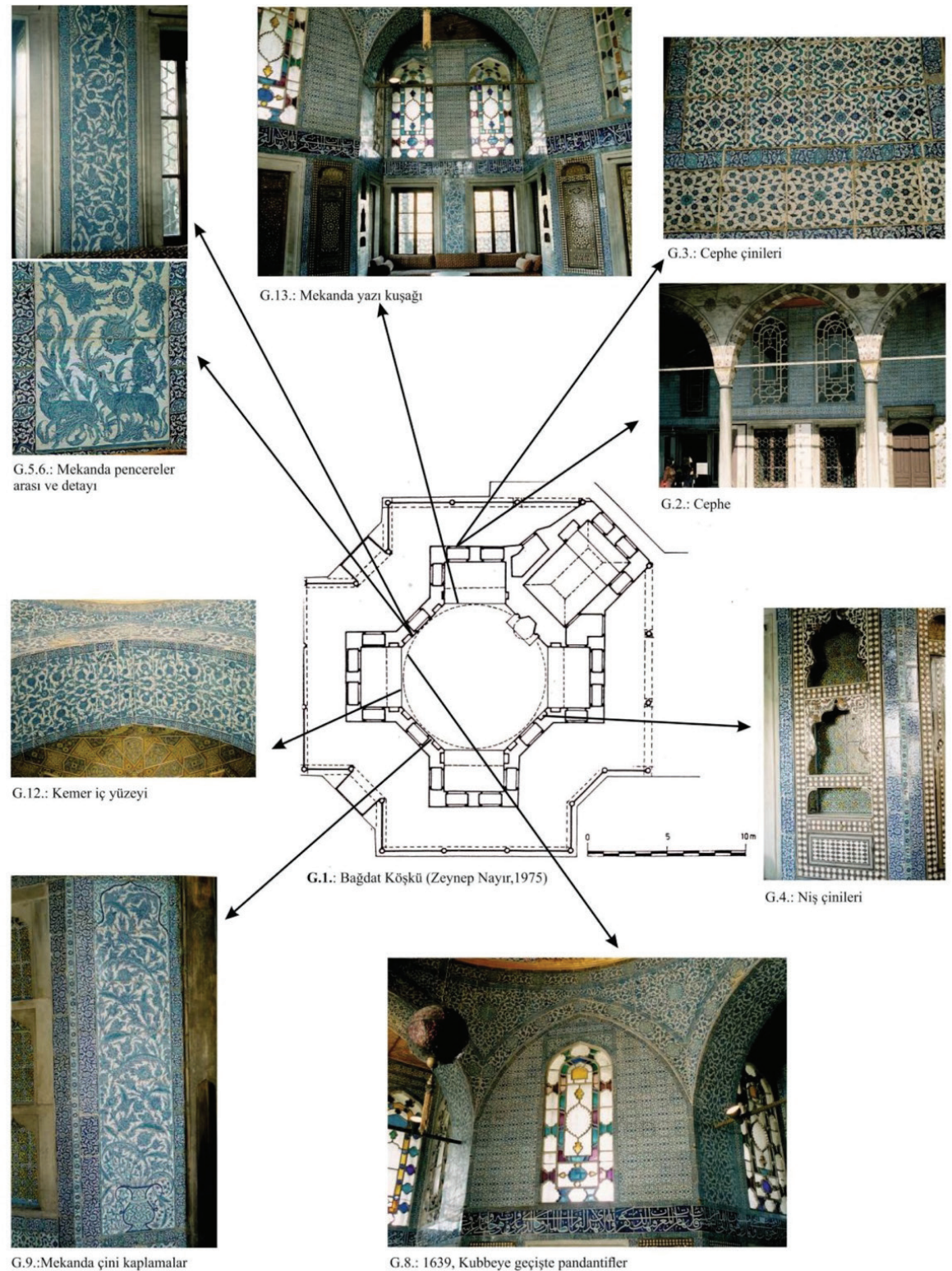

G. 1: Bağdat Köşkü Planı (Zeynep Nayır, 1975)

Yapının diş cephelerinde alt pencerelerin üstü Revan Köşkü (1635)'nde olduğu gibi çinilerle donatılmıştır. İç kısımda pandantifler, eyvan kemerleri, pencere araları ve dolap içleri çini kaplıdır. Topkapı Sarayı Haremi Bağdat Köşkü’nde yer alan celisülüs hatlı Ayetel Kürsi'yi, Tophaneli Enderuni Mahmud Çelebi'nin yazdığg bilinmektedir 5 .

5 Mustakimzade eserinde Tophaneli Mahmud olarak tanınan sanatçıyı tanıtmakla birlikte Bağdat Köşkü (1939) yazılarını yazdığına dair bir bilgi vermemiştir. Müstakimzade Süleyman Saadeddin Efendi, Tuhfe-i Hattatin, (İstanbul, Devlet Matbaas1, 1928), 511-512. Reşat Ekrem Koçu’nun İstanbul Ansiklopedisi "Bağdat Köşkü” 
Bu çalışmanın amacı günümüze ulaşan Türk mimarisini en güzel köşklerinden biri olan Bağdat Köşkü’nü süsleyen çinileri incelemek, 17. yüzyılın başarılı örnekleri olan bu çinileri süsleme, teknik ve üretim yerleri açısından değerlendirmek ve 17 . yüzyıl çinilerinin bulunduğu diğer yapılarla karşılaştırarak dönemi içindeki yerini tespit etmektir.

Yapının içini ve dışını süsleyen çini süsleme tasarımını desen özelliklerine göre dışarıdan içeriye doğru şu şekilde sınıflandırabiliriz:

\section{1. Çin Bulutu Hatayiler}

Topkapı Sarayı Bağdat Köşkü cephe ve mekânda pencere aralarında Çin bulutu hatayiler yer alır. Bu çiniler merkezi palmet biçimli sekiz kollu bir rozet çiçeği ile bunu çevreleyen kıvrık dallı hatayilerle ve hatayileri çevreleyen S kıvrımlı Çin bulutları ile süslenmiştir. Sonsuzluk anlayışı ile verilen düzenlemede süsleme her levhada bir motif, iki levhanın birleşmesi ile üstteki Çin bulutları ve yanlardaki yarım hatayilerden meydana gelmiş̧ir. Bütünü dört levhanın birleşmesi ile köşelerdeki çiçekler dörtlü bir kuruluşla oluşturmuştur. Bordürleri ise atlamalı olarak yer alan Çin bulutu dolgulu yaprak biçimli dilimli ve palmet biçimli madalyonlar ve araları helezon dallı süslemeler tamamlar. Çiniler sır altına boyama tekniğinde, ana desen lacivert zemin üzerine firuze, beyaz renk kullanımı ile oluşturulmuştur. Bordür çinilerinde ise beyaz zemin üzerine firuze, mavi renk kullanılmıştır. Çiniler 28 x $28 \mathrm{~cm}$ boyutlu levhalardan, bordür ise 12.5 x $25 \mathrm{~cm}$ boyutlu çinilerden oluşur (G. 2, G. 3). Kütahya üretimi olduğu düşünülen bu çinilerin benzerleri Topkapı Sarayı Revan Köşkü cephesinde yer alır.

\section{Helezon Kuruluşlu Kıvrık Dallı Hatayiler}

Topkapı Sarayı Bağdat Köşkü cephede üst ve alt pencerelerin sınırlandığı bölümde helezon kuruluşlu, kıvrık dallı hatayiler yer alır. Çiniler palmetli sekiz kollu yıldız biçimli rozet, bunu çevreleyen helezon kuruluşlu kıvrık dallı şakayıklar ve hatayilerden oluşan bir süslemeye sahiptir. Sonsuzluk anlayışı ile verilen düzenlemede süsleme, her levhada bir motif, dört levhanın birleşmesi ile köşelerde yer alan çeyrek yıldızlar bütünü tamamlar. Bordürleri ise atlamalı olarak yer alan Çin bulutu dolgulu yaprak biçimli dilimli ve palmet biçimli madalyonlar oluşturur. Aralarında helezon dallı süslemeler vardır. Çinilerde sır altına boyama tekniğinde, beyaz zemin üzerine firuze, mavi renk kullanılmıştır. Çiniler $28 \times 28 \mathrm{~cm}$, bordür çinileri ise $12.5 \times 25 \mathrm{~cm}$ boyutlu levhalardan oluşur (G.2, G.3). Kütahya üretimi olduğu düşünülen çinilerin benzerleri Üsküdar Çinili Camii (1640) son cemaat yeri ve kadınlar mahfilinde yer alır. Söz konusu çinilerdeki desenler Haliç̧ Işi adı ile anılan İznik seramikleri ile de benzerlik gösterir.

maddesinde yapı için dönemin vak'anüvisi Naima'nın yapının içindeki yazıları yazan hattatın Tophaneli Mahmud Çelebi olduğunu ve bu emrin IV. Murad (1623-1640) tarafindan verildiğini belirttiği bilgisi yer almaktadır. Bakınız Reşat Ekrem Koçu, "Bağdat Köşkü," İstanbul Ansiklopedisi, c. IV (İstanbul: Tan Matbaası, 1960), 1804-1808; Gönül Öney, Türk Çini Sanatı/Turkish Tile Art (İstanbul: Yapı Kredi Yayınları, 1976), 109. 


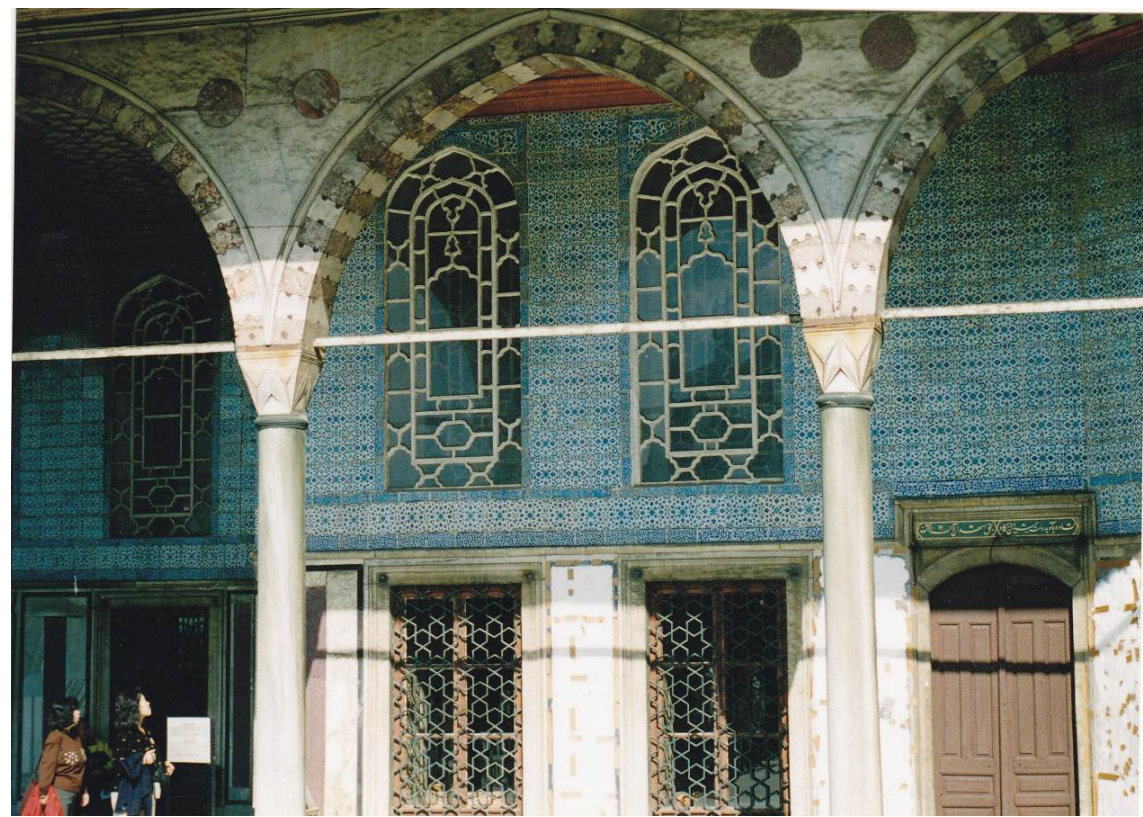

G. 2: Bağdat Köşkü Sephe (E. Emine Naza Dönmez Arşivi)

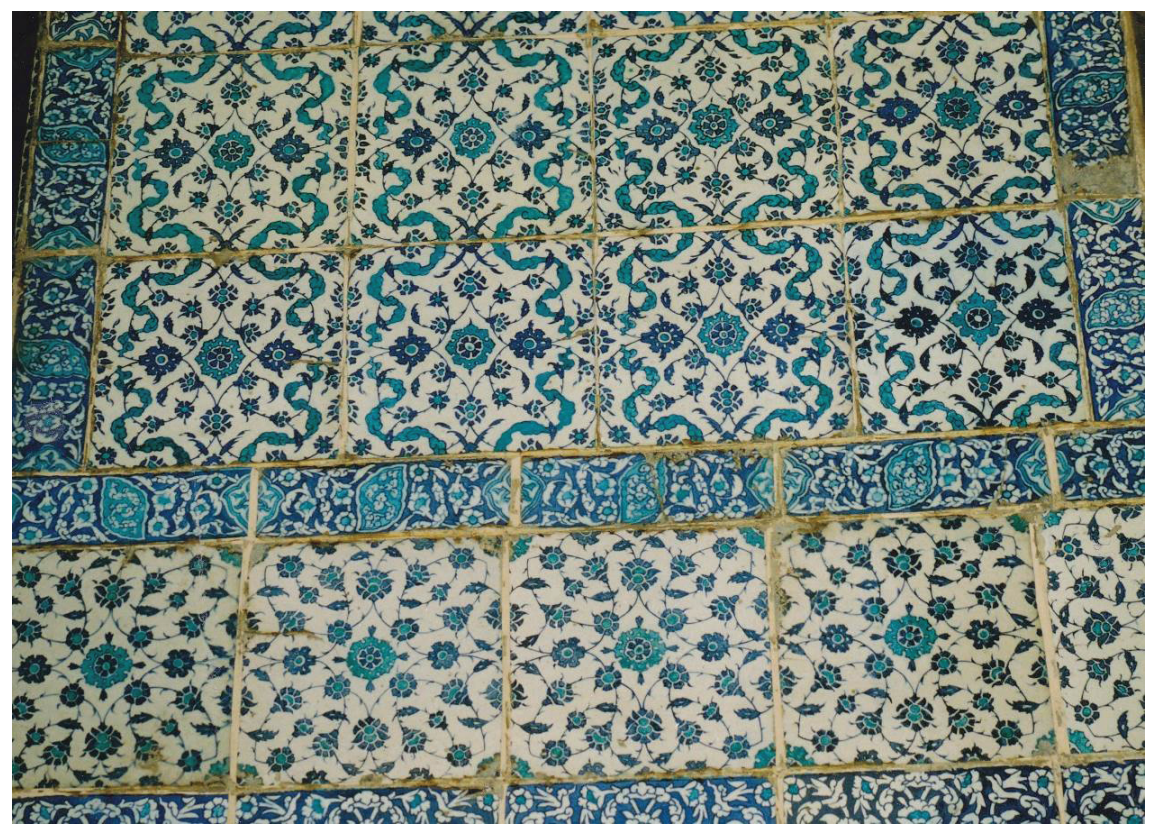

G. 3: Bağdat Köşkü Cephe Çinileri (E. Emine Naza Dönmez Arşivi) 


\section{Daire Kuruluşlu Lotus-Şakayık Süslemesi}

Topkapı Sarayı Bağdat Köşkü dolap raflarında daire kuruluşlu lotus-şakayık süslemeleri yer alır. Çinilerin süslemesi, ortada sekiz kollu bir yıldız, bu yıldızlardan çıkan daire biçimi oluşturan dört lotus ve yine bu yıldızlardan çıkan ara boşlukları dolduran şakayıklardan oluşur. Sonsuzluk anlayışı ile verilen düzenlemede, süsleme dört çini levhanın birleşmesi ile ortaya çıkar. Levhaların birleşmesi ile köşelerde sekiz kollu yıldızlar oluşmuştur. Dolap raflarında yer alan 25 x $25 \mathrm{~cm}$ boyutlu levhalardan oluşan bu çiniler renkli sırla boyama tekniğinde depo çinileridir ${ }^{6}$ (G. 4). Yeşil, sarı, lacivert, beyaz renk kullanılmıştır? ${ }^{7}$ Benzer teknik ve süsleme Topkapı Sarayı Arz Odası (16. yy) cephesinde yer alır. Benzer süsleme ise Çinili Köşk (1472) giriş revakında mozaik çini olarak verilmiştir. Yeni Camii, Topkapı Sarayı Haremi Veliaht Dairesi (1666) cephesinde ise sir altına boyama tekniğinde, beyaz zemin üzerine mavi ve firuze renk kullanılmıştır. Söz konusu süsleme Rüstem Paşa Camii (1560) çinileri üzerinde de yer alır.

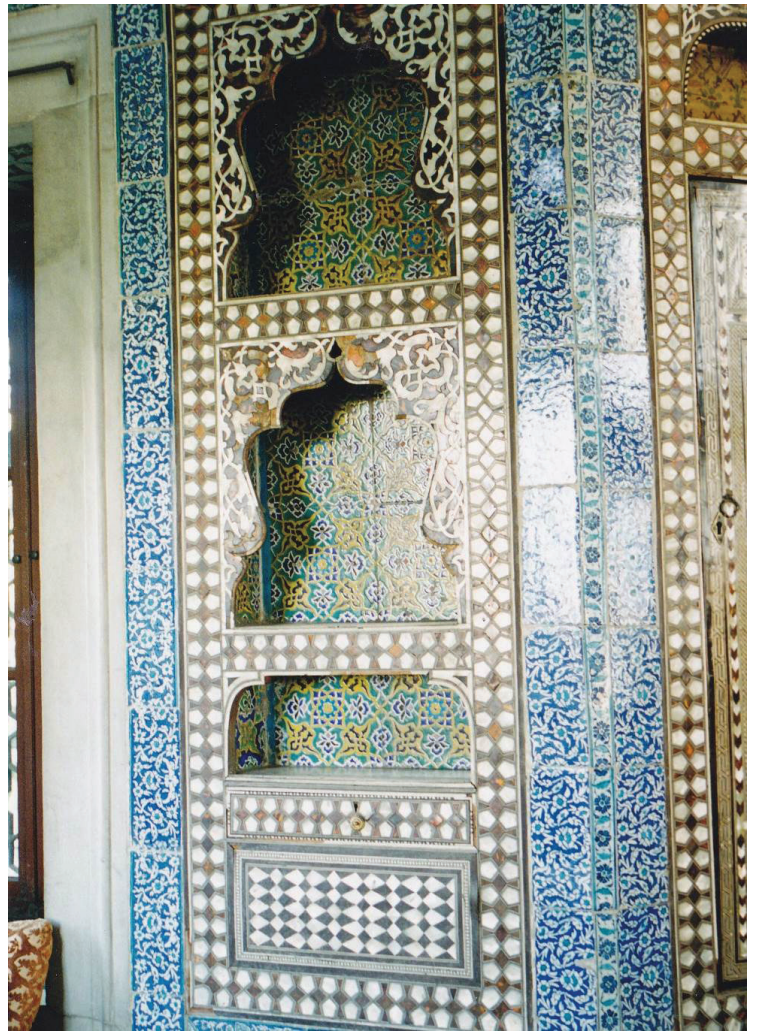

G. 4: Bağdat Köşkü Niş Çinileri (E. Emine Naza Dönmez Arşivi)

6 Renkli sırlı eserler için bk. Dönmez, “Osmanlı Dönemi Türk Çini Sanatı (Erken, Klasik, Geç Devirler),”, 366.

7 Funda Koçer Yeşilyurt. söz konusu çinilerin renklerinden ötürü Habib atölyesinden üretildiğini belirtmiştir. Koçer Yeşilyurt, "Topkapı Sarayı Dördüncü Avludaki Yapılarda Kullanılan Çiniler,” 19. Habib atölyesi için bk. Faik Kırımlı, "İstanbul Çiniciliği," Sanat Tarihi Yıllı̆̆ XI (1981), 87; Gülru Necipoğlu, "From International Timurid to Ottoman: A Change of Taste in Sixteenth-Century Ceramic Tiles," Muqarnas 7 (1990), 102; Venetia Porter, Islamic Tiles (London: The British Museum Press, 2008), 102. 


\section{Saz Üslubunda Kilinli Pano}

Saz üslubunda kilinli pano, Topkapı Sarayı Bağdat Köşkü mekânda pencere arasında yer alır. Çinilerin süslemesi Çin bulutu dolgulu dekoratif kemer içinde, saz üslubunda kıvrık dallı hatayiler ve şakayıklardan oluşur. Panonun alt kısmında saz yapraklar arasında iki kilin ${ }^{8}$ figürü vardır. Hatayilerin üzerinde kuşlar yer alır. Süsleme bir bütün olarak tasarlanmış ve levhalara aktarılmıştır. Bordürleri ise atlamalı olarak yer alan Çin bulutu dolgulu yaprak biçimli dilimli ve palmet biçimli madalyonlar ile araları helezon dallı süslemelerden oluşur. Çinilerde sır altına boyama tekniği, beyaz zemin üzerine firuze, mavi renk kullanılmıştır. Kilinlerin dilleri kırmızı olarak belirtilmiştir. Üretim yeri İznik olan çiniler 32 x 49 ve 31 x $44 \mathrm{~cm}$ boyutlu yedi çini levhadan oluşur (G. 5, G. 6). Bordür çinilerinin ölçüleri ise $25 \times 12.5$ cm'dir. Bu çiniler Topkapı Sarayı Sünnet Odası (1640) cephesinde ${ }^{9}$ yer alan 16. yüzyıl çinilerinin kopyasıdır (G. 7).

\section{5. Çin Bulutu Dolgulu Şemse ve Rumi Dalları}

Topkapı Sarayı Bağdat Köşkü kubbeye geçişte pandantiflerde Çin bulutu dolgulu şemse ve rumi dallar kullanılmıştır. Süsleme, paralel dilimli Çin bulutu dolgulu şemseler, bu süslemeyi çevreleyen helezon kuruluşlu rumi dalları ve boşlukları dolgulayan hatayilerden oluşur. Bulunduğu yere göre tasarlanmış olan çini süsleme, bordürlerle birlikte bir bütün olarak verilmiş ve levhalara aktarılmıştır. Bordürler ise atlamalı olarak yer alan Çin bulutu dolgulu yaprak biçimi dilimli ve palmet biçimi madalyonlar ile araları helezon dallı süslemelerden oluşur. Çinilerde sır altına boyama tekniği, beyaz zemin üzerine firuze, mavi renk kullanılmıştır. Pandantif çinilerinin ölçüleri 25 x 25 cm'dir (G. 8). Benzer çini süslemeleri Rüstem Paşa Camii'nde (1560), mekânda mahfil kemerleri köşelerinde yer alır.

8 Kilin (ch'ilin=ejder atı) bir efsane hayvanıdır. Bu yaratığın gövdesi misk geyiği, kuyruğu öküz kuyruğu, alnı kurt alnı ve ayakları at ayağı biçimindedir. Suda ve karada yürüdüğüne inanılan bu yaratığın erkeğine "ch'i", dişisine "lin" denilmekte ve erkeğinin başında tek boynuz bulunmaktadır. İkisi birleştirilerek "ch'ilin" adını almıştır. Bk. Banu Mahir, "Osmanlı Sanatında Saz Üslubundan Anlaşılan,” Topkapı Sarayı Müzesi Yıllık 2(1987), 130.

9 Kurt, Erdmann, "Die Fliesen am Sünnet Odasi des Top Kapı Saray in İstanbul," Aus der Welt Der Islamischen Kunst Festschrift für Ernst Kühnel (Berlin: Verlag Gebr. Mann, 1959), 144-153. Ayrıca bu çiniler ve etkileşimi için bakınız Necipoğlu, "From International Timurid to Ottoman: A Change of Taste in Sixteenth-Century Ceramic Tiles", 136-170. 


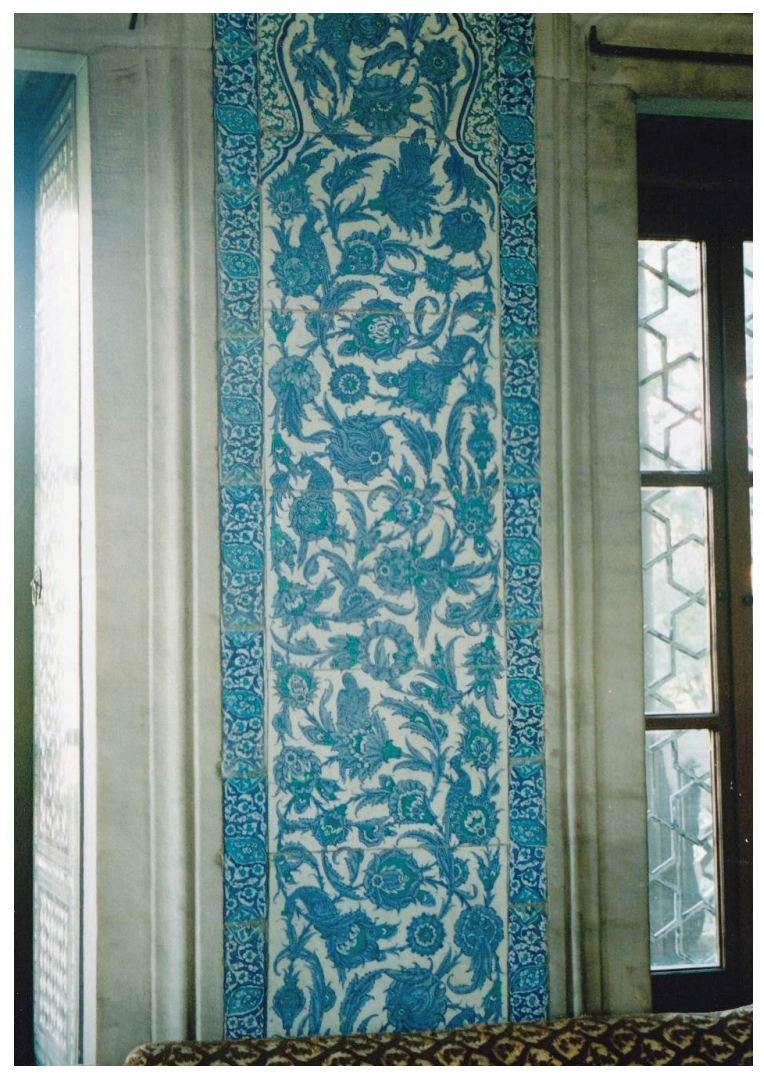

G. 5: Bağdat Köşkü Mekânda Pencereler Arası (E. Emine Naza Dönmez Arşivi) 


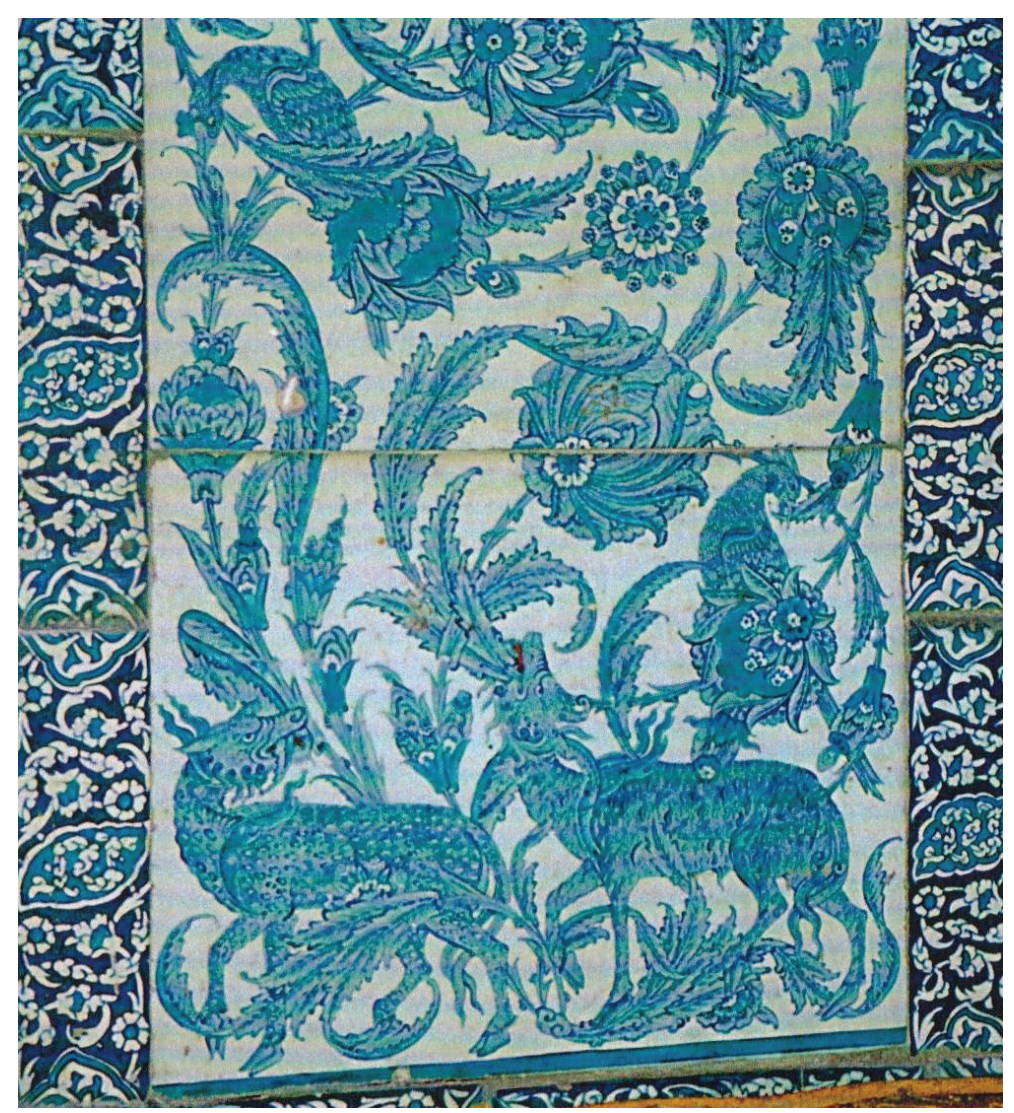

G. 6: Bağdat Köşkü Mekânda Pencereler Arası Detay (E. Emine Naza Dönmez Arşivi) 


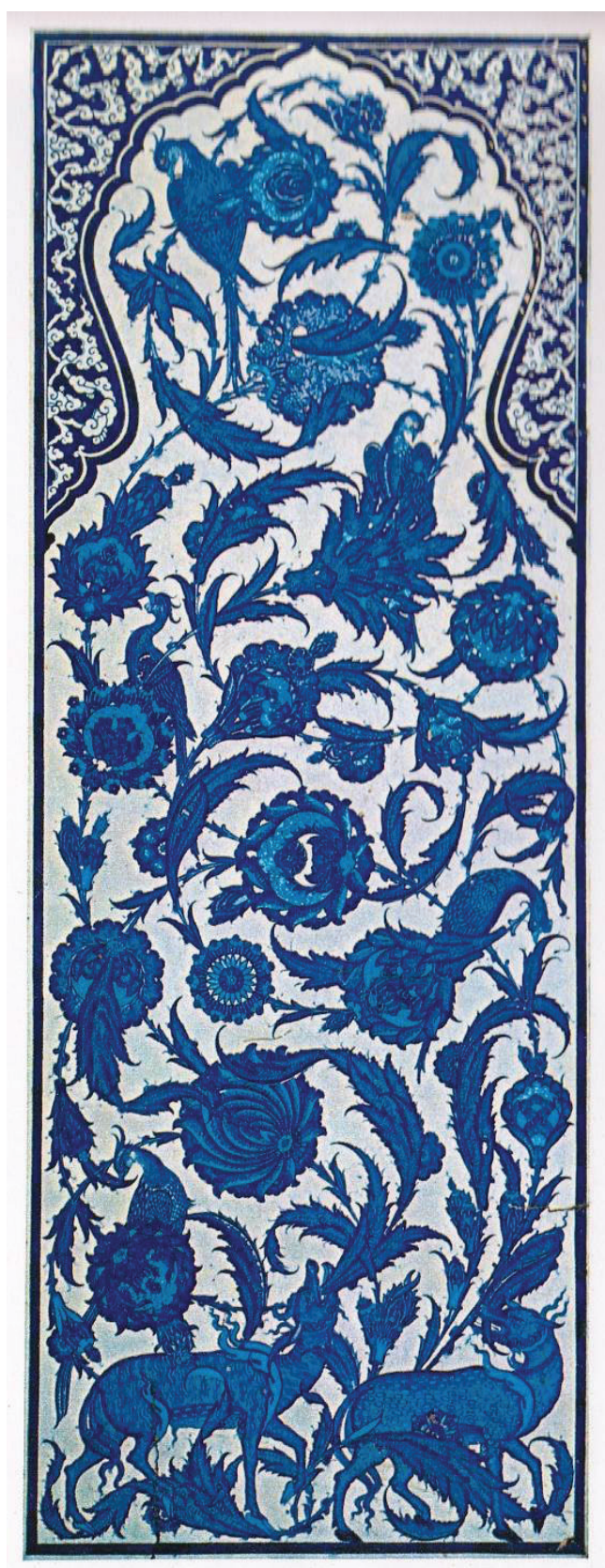

G. 7: Topkap1 Sarayı Sünnet Odası Cephesi (Deniz Esemenli, 2000) 


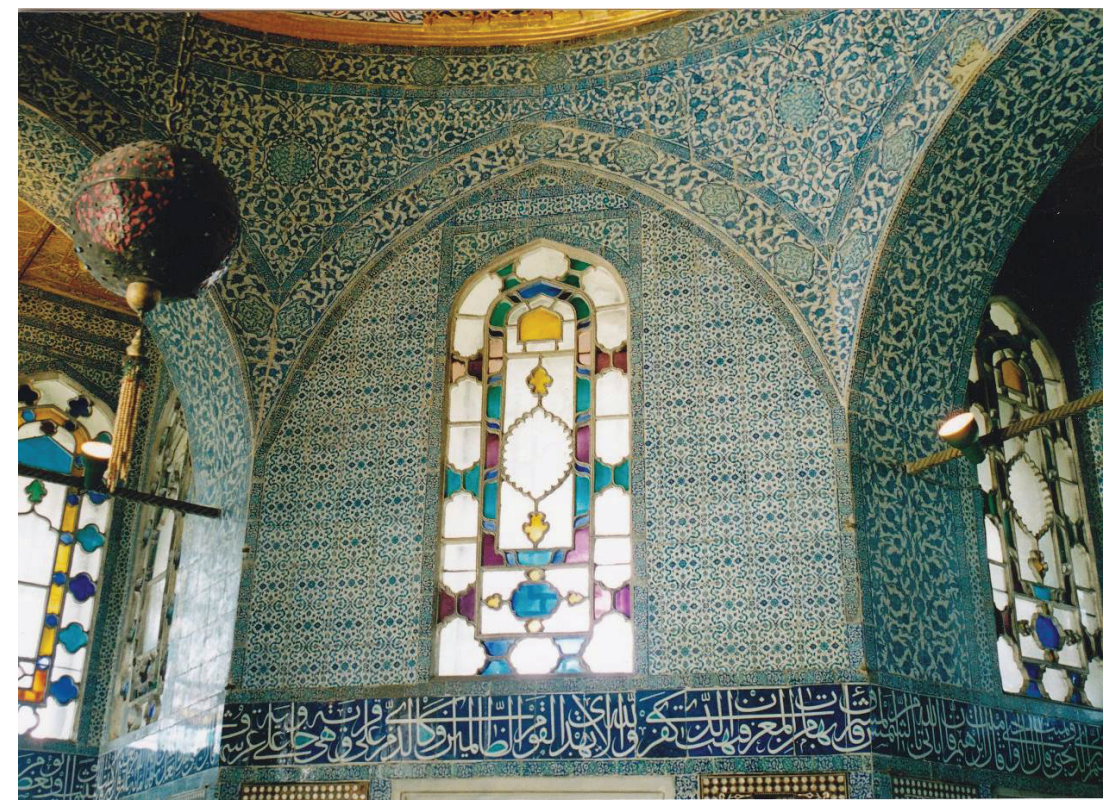

G. 8: Bağdat Köşkü 1639, Kubbeye Geçişte Pandantifler (E. Emine Naza Dönmez Arşivi)

\section{Saz Üslubunda Ayaklı Vazodan Çıkan Hatayiler}

Topkapı Sarayı Bağdat Köşkü mekânda ocağın yan bölümlerinde saz üslubunda ayaklı vazodan çıkan hatayiler yer alır. Süsleme rumi dolgulu dilimli kemer içinde yer alan, yüzeyi rumili, ayaklı, şişkin karınlı, geniş ağızlı, kulplu vazodan çıkan iri saz yapraklar ve hatayilerden oluşur. Yaprakların üzerinde kuş figürleri vardır. Süsleme bir bütün olarak tasarlanmış ve levhalara aktarılmıştır. Sır altı tekniğinde beyaz zemin üzerine firuze, mavi renk kullanılmıştır. Kuşların gagaları kırmızı renkte verilmiştir. Çiniler 32 x 49 ve 31 x $44 \mathrm{~cm}$ boyutlarında yedi levhadan oluşmaktadır. Bordür süslemesi ise $\mathrm{S}$ kıvrımlı Çin bulutları arasında şakayıklardan meydana gelir. Sır altına boyama tekniğinde, lacivert zemin üzerine firuze, beyaz renk kullanılmıştır. Bordür çinileri 12.5 x $25 \mathrm{~cm}$ boyutlu levhalardan oluşur (G. 9). 17. yüzyılın bu en kaliteli İznik üretimi çinilerinin bir benzeri Kahire Aksungur Camii (1347 ilk yapım 1652 çini kaplamalar) mihrap duvarında yer alır (G. 10). Aynı yüzyılda inşa edilmiş olan Topkapı Sarayı Sünnet Odası cephesinde ise aynı süslemeden oluşan 16. yüzyıl çinileri bulunmaktadır (G.11). İtalya' da Roma Stroganoff Sarayı1 ${ }^{10}$ (19. yüzyıl) ocak çinilerinin süslemelerindeki benzerlik ise Osmanlı etkisini yansıtmaktadır.

10 Erdmann, "Die Fliesen am Sünnet Odasi des Top Kapı Saray in İstanbul,” 144-153; Maria Vittoria, Fontana, "İmitations of İznik Ceramics Produced by the Neapolitan Delle Donne Factory for the Stroganoff Palace in Rome," First International Congress on Turkish Tiles and Ceramics (6-11.VII.1986 - Kütahya) (İstanbul: Türk Petrol Vakfi,1989), 119-142. 


\section{Saz Üslubunda Kıvrık Dalı Hatayili Süsleme}

Topkap1 Saray1 Bağdat Köşkü kemer iç yüzeyindeki çinilerin süslemesi saz üslubunda kıvrık dallı hatayiler ve şakayıklardan oluşur. Sonsuzluk anlayışı ile verilen düzenlemede süsleme, bordürlerle beraber bir bütün olarak tasarlanmış ve levhalara aktarılmıştır. Sır altına boyama tekniğindeki çinilerde beyaz zemin üzerine firuze, mavi renk kullanılmıştır. Bu çiniler 25 x $25 \mathrm{~cm}$ boyutlu olarak kemer iç yüzeyine uygun olarak kesilmiştir. Bordürleri ise atlamalı olarak yer alan Çin bulutu dolgulu yaprak biçimli dilimli ve palmet biçimli madalyonlar ile araları helezon dallı süslemelerden oluşur (G. 12). Benzer süsleme Kılıç Ali Paşa Camii (1587) müezzin mahfilinin altında kalemişi olarak karşımıza çıkar.

\section{Madalyon Biçimli Palmetler}

Topkapı Sarayı Bağdat Köşkü kemer ve kubbe eteği bordürlerinde yer alan çinilerin süslemesi rumi palmet dolgulu madalyon biçimli palmetler ve bunları çevreleyen hatayili dallardan oluşur. Sonsuzluk anlayışı ile verilen düzenlemede süsleme, bordürlerle birlikte bir bütün olarak tasarlanmış ve levhalara aktarılmıştır. Sır altına boyama tekniğinde çinilerde beyaz zemin üzerine firuze, mavi renk kullanılmıştır. Bordürleri ise atlamalı olarak yer alan Çin bulutu dolgulu yaprak biçimli dilimli ve palmet biçimli madalyonlar ile araları helezon dallı süslemelerden oluşur. Çiniler 25 x $25 \mathrm{~cm}$. boyutlarındadır (G. 8).

\section{9. Çin Bulutu Dolgulu Şemse ve Rumi Dalları}

Topkapı Sarayı Bağdat Köşkü kubbeye geçişte pandantiflerde Çin bulutu dolgulu şemse ve rumi dalları kullanılmıştır. Çinilerin süslemesi paralel dilimli Çin bulutu dolgulu şemseler, bu süslemeyi çevreleyen helezon kuruluşlu rumi dalları ve boşlukları dolgulayan hatayilerden oluşur. Bulunduğu yere göre tasarlanmış olan çini süsleme, bordürlerle birlikte bir bütün olarak verilmiş ve levhalara aktarılmıştır. 25 x $25 \mathrm{~cm}$ boyutlu levhalardan oluşan çinilerde sır altına boyama tekniği beyaz zemin üzerine firuze, mavi renk kullanılmıştır. Bordürleri ise atlamalı olarak yer alan Çin bulutu dolgulu yaprak biçimli dilimli ve palmet biçimli madalyonlar ile araları helezon dallı süslemelerden oluşur (G. 8). Benzer süsleme Rüstem Paşa Camii, mekânda mahfil kemerleri köşe çinilerinde yer alır. 


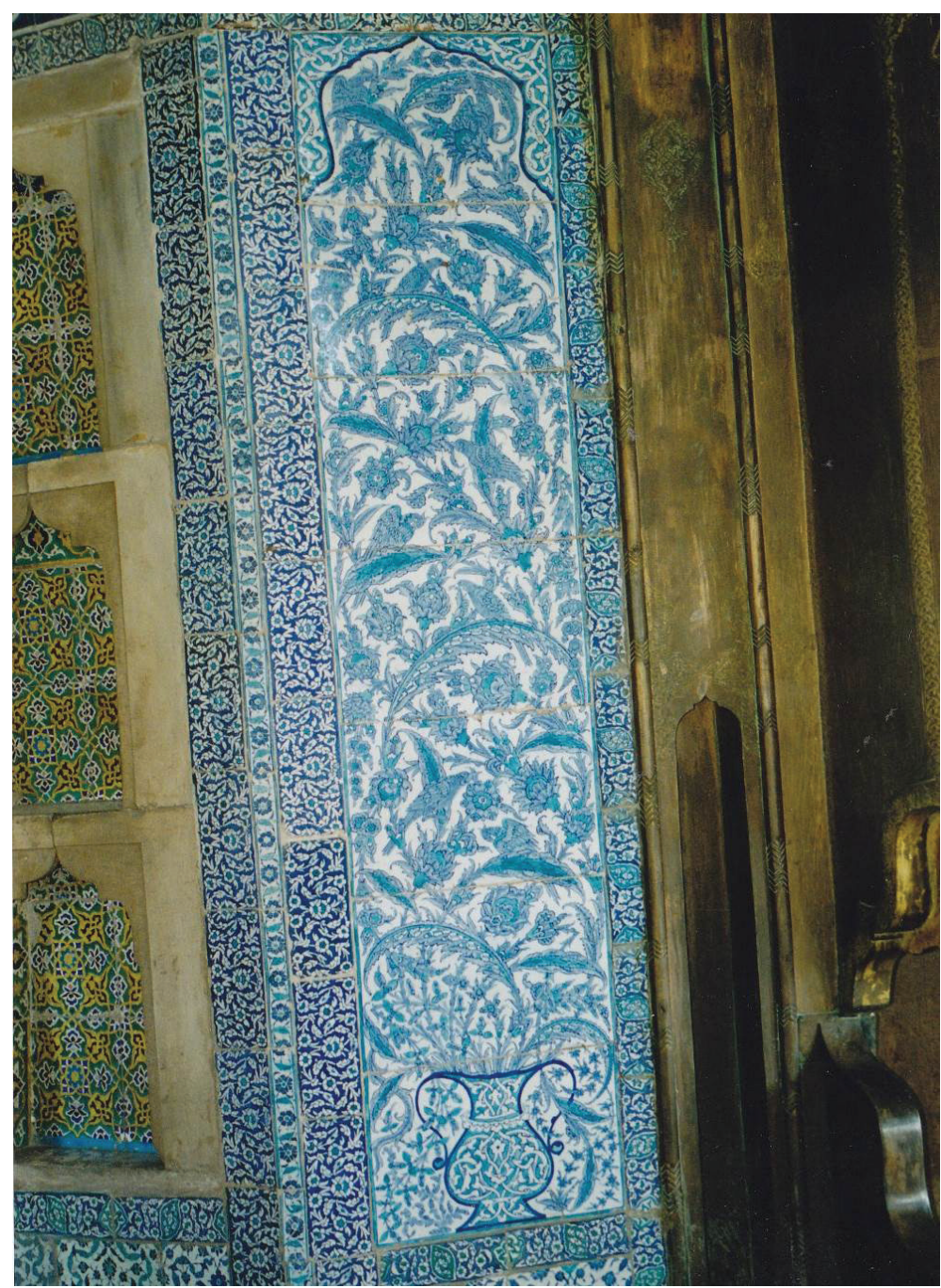

G. 9: Bağdat Köşkü Mekânda Çini Kaplamalar (E. Emine Naza Dönmez Arşivi) 


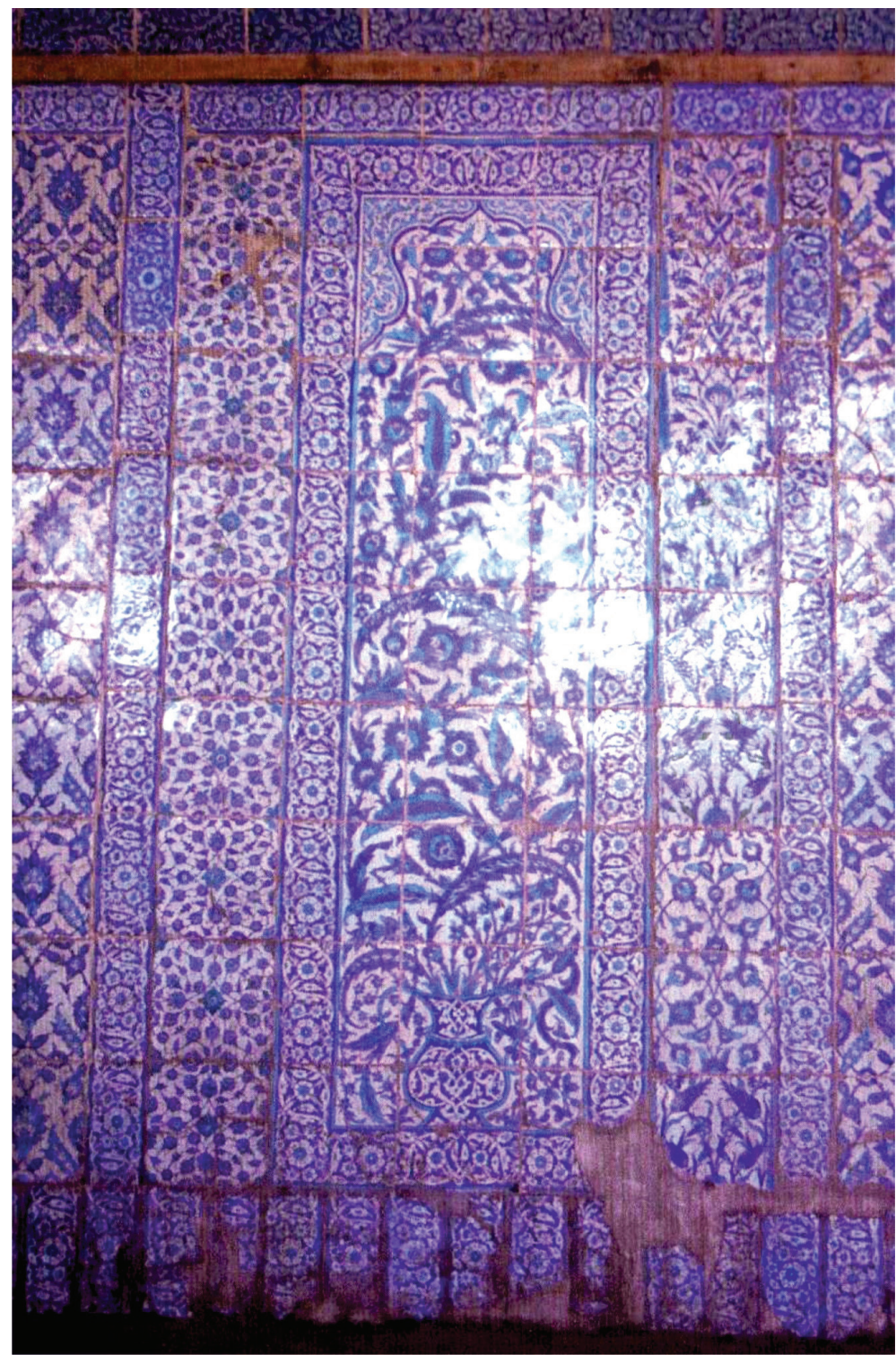

G. 10: Kahire Aksungur Camii Mihrap Duvarı (M. Baha Tanman Arşivi) 


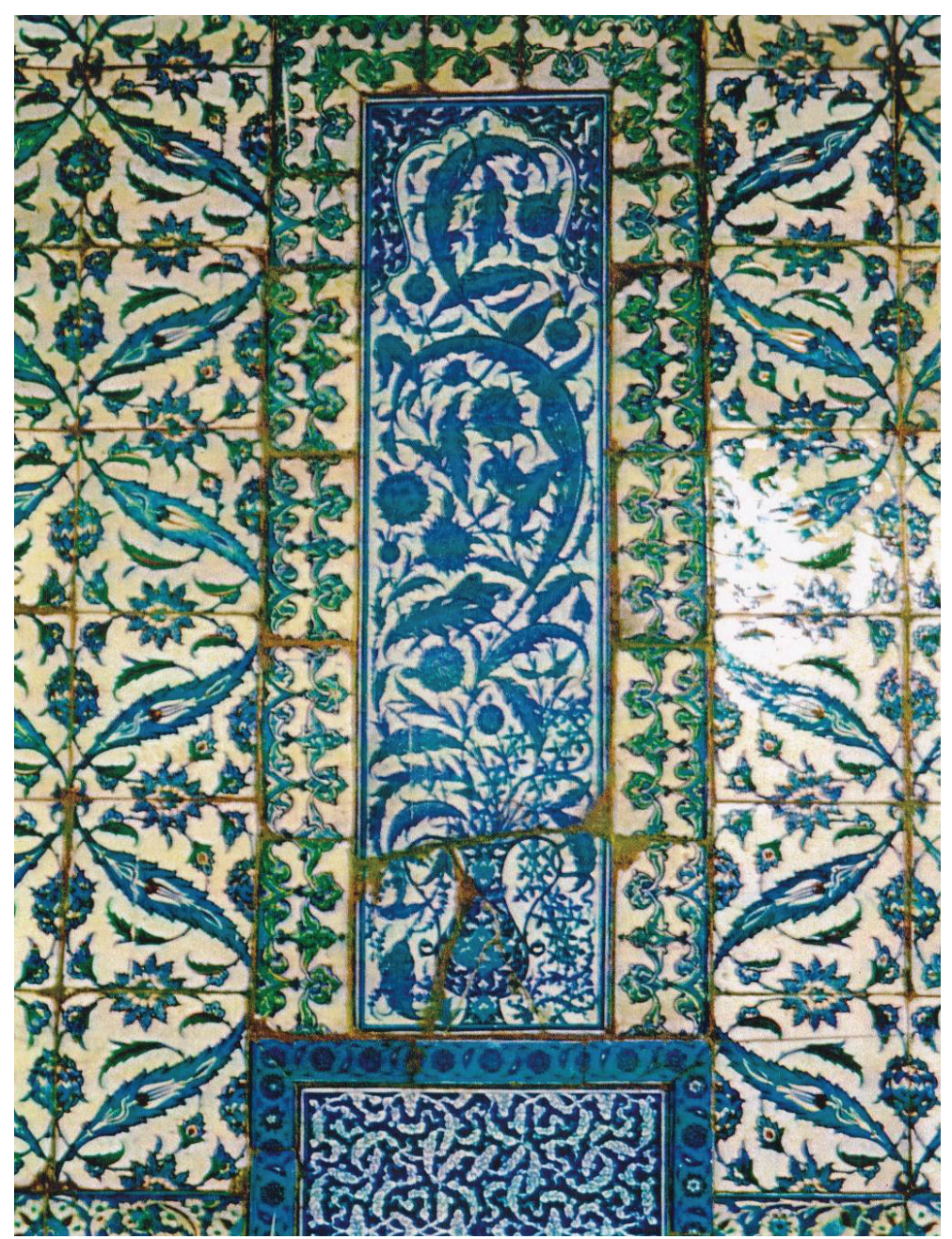

G. 11: Topkap1 Saray1 Sünnet Odası (Deniz Esemenli, 2000) 


\section{Yazı}

Topkapı Sarayı Bağdat Köşkü Mekânı çevreleyen celi sülüs yazı kuşağı, ocağın sağından başlayarak alt pencerelerinin arasında dolanarak ocağın solunda tamamlanır. “Ayet el Kürsi" ve devamında Bakara suresinin 127. ayetinin yazıldığ hat $^{11}$ yazısı bir bütün olarak tasarlanmış ve levhalara aktarılmıştır. Bordürleri ise atlamalı olarak yer alan Çin bulutu dolgulu yaprak biçimli dilimli ve palmet biçimli madalyonlar ve araları helezon dallı süslemelerden oluşur. Çiniler sır altına boyama tekniğinde olup lacivert zemin üzerine, beyaz renk kullanılmış ve harf boşlukları firuze renkle dolgulanmıştır. Bordür çinilerinde ise beyaz zemin üzerine firuze, mavi renk kullanılmıştır. Çiniler 2 x $37.5 \mathrm{~cm}$ boyutludur. Bordür çinilerinin ölçüleri 25 x $12.5 \mathrm{~cm}$ ’dir (G. 13).

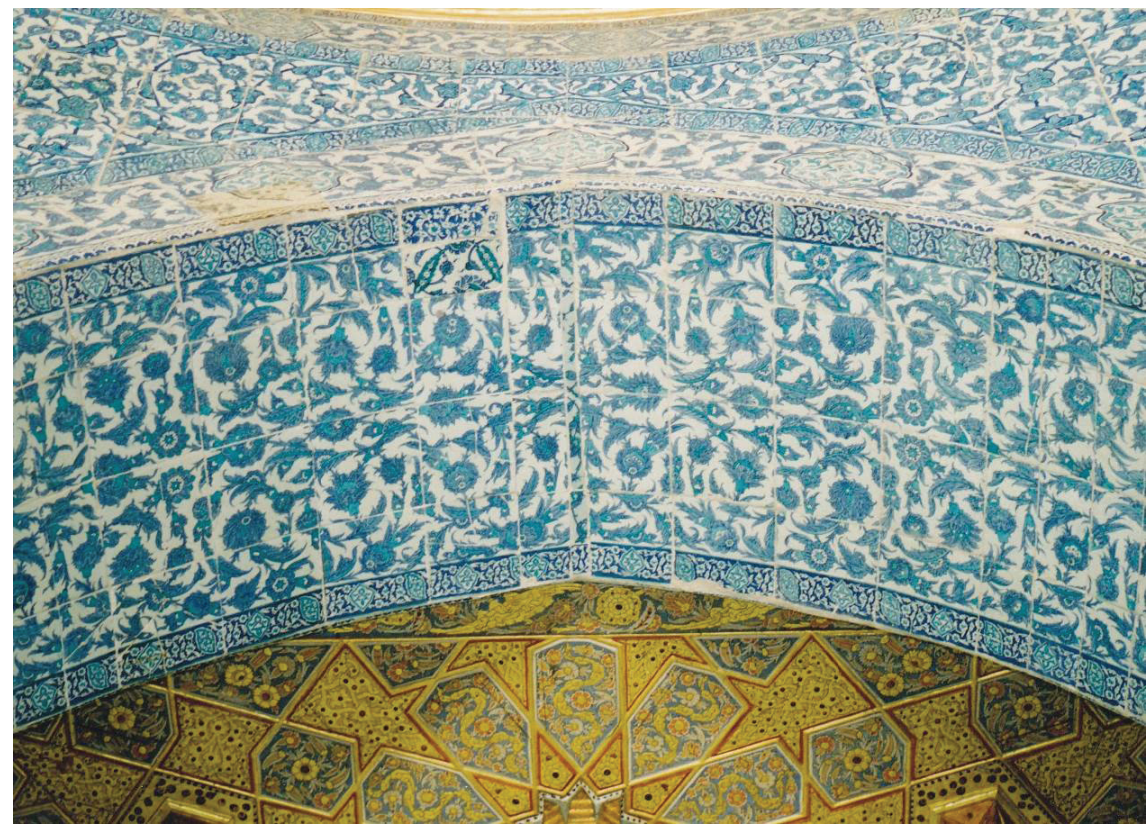

G. 12: Bağdat Köşkü Kemer İç Yüzeyi (E. Emine Naza Dönmez Arşivi) 


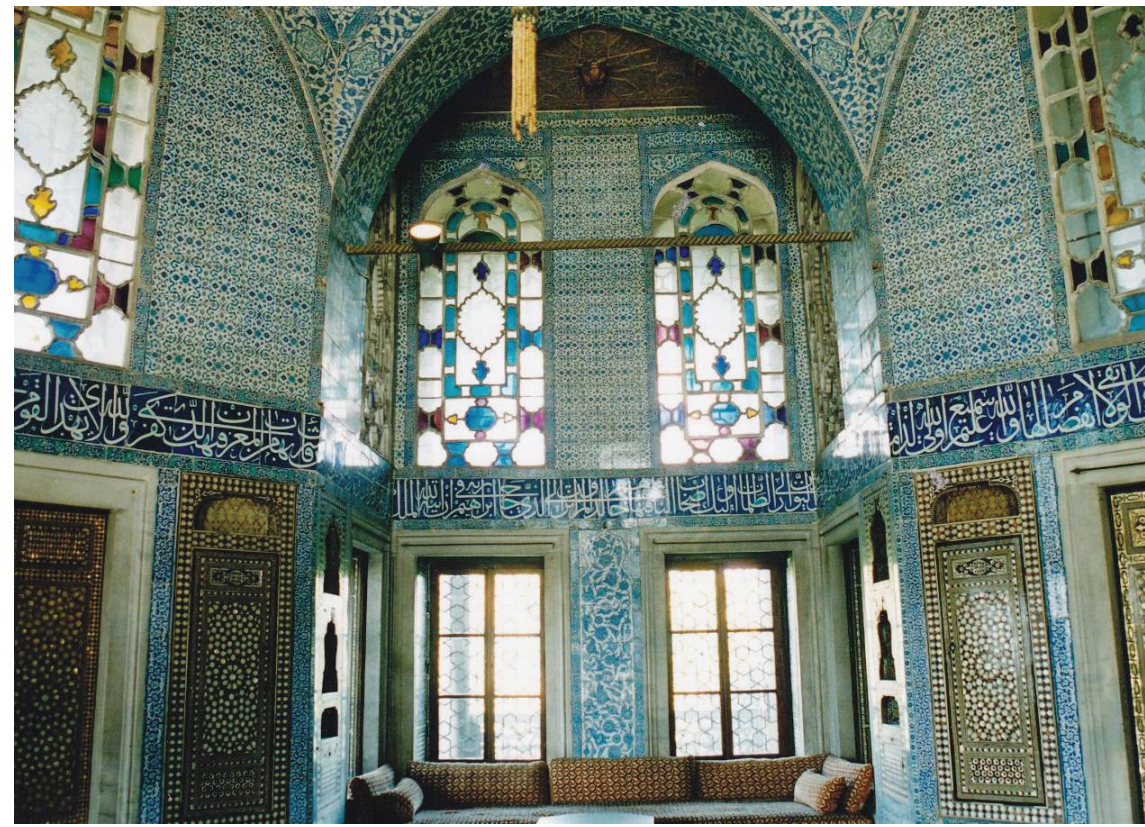

G. 13: Bağdat Köşkü Mekânda Yazı Kuşağı (E. Emine Naza Dönmez Arşivi)

\section{Değerlendirme}

Topkapı Sarayı dördüncü avlusundaki Sarayın en güzel manzarasını seyreden Bağdat Köşkü merkezi kubbeli, dört eyvanlı bir yapıdır. İki sıra pencereli yapıyı dışarıdan çevreleyen bir revakı bulunur. Yapının dış cephelerinde alt pencerelerin üstü çinilerle donatılmıştır. Yapının içinde ise pandantifler, eyvan kemerleri, pencere araları ve dolap içleri çini kaplıdır. Dolap içindeki renkli sır tekniğindeki çiniler 16. yüzyılın depo çinileridir ${ }^{12}$. Köşkün çini süslemelerinin büyük bir kısmı hatayi, ${ }^{13}$ mekânda ocağın iki yanında ve pencere aralarında yer alan kuş ve kilin figürlerinin de bulunduğu panolar ise saz üslubundadır. 16. yüzyıldan başlayarak 17. yüzyıl ortalarına kadar devam eden mürekkep çalışmaları ve bu çalışmalarda görülen sivri uçlu saz yapraklar, hatayiler ve efsanevi hayvanların dışında melek figürlerinin yer aldığı albüm resimlerine $s a z$ yolu veya saz üslubu denmiştir. Bu üslubu Saray çevresinde başlatan kişi Nakkaşbaşı Şah Kulu'dur. Özellikle Şah Kulu'nun yapmış olduğu albüm resimlerinde bu üslup

12 17. yüzyılda inşa edilen yapılarda, 16. yüzyıl depo çinileri de kullanılmıştır. Bunlar, 16. yüzyılda kullanılmayan ve büyük bir olasılıkla Topkapı Sarayı'nda bir mekânda saklanmış olan çinilerdir. Söz konusu renkli sırlı niş çinileri ve Sünnet Odası cephesindeki 16. yüzyıl çinilerin kullanımına böyle bir açıklık getirilebilir. 17. yüzyı1 yapılarında 16. yüzyıl çinilerinin kullanımı için bakınız E. Emine Naza Dönmez, "Türk Çini Sanatının Sürekliliği İçinde XVII. Yüzyıl Eserlerinin Yeri” (Doktora tezi, İstanbul Üniversitesi, 2001), 32.

13 Hatayi süslemede Hıtay, Kuzey Türkistan'ı ifade eder. Günümüzde bu bölge Batı'da Çin Türkistan’ı olarak ifade edilir. Hatayi süslemesinin Çin'de yaygın bir kullanımı olmuştur. Genellikle soyut olarak verilen bitki süslemelerinin yanında, şakayıklar da yer almıştır. Bakınız İnci Birol ve Çiçek Derman, Türk Tezyini Sanatlarında Motifler (İstanbul: Kubbealtı Yayınevi, 1991), 65; M. Mizuno Yamanlar, "Hatayi Motifinin Menşei," 9. Milletlerarası Türk Sanatları Kongresi, 3. cilt (Ankara: Kültür Bakanlığı, 1995), 445-445; Sitare Turan Bakır, İznik Çinileri ve Gülbenkyan Kolleksiyonu (Ankara: Kültür Bakanlığı1, 1999), 189. 
büyük bir başarı ile ortaya konmuştur. Bu üslubu devam ettiren Nakkaş Veli Can'ın çalışmaları da başarılıdır. Saz yolu veya saz üslubu terimi çeşitli araştırmacılar tarafindan kullanılmıştır. Walter B. Denny bu terimin mürekkep çalışmalarında kullanılan saz kalemler sebebiyle olduğunu belirtmiştir ${ }^{14}$. XVI. yüzyıl ortalarında başlayıp diğer sanat kollarında yaygın olarak kullanılan, çini, tezhip, kumaş, cilt, kalemişi süslemelerinde de görülen bu süsleme üslubu, 18. yüzyılda lake sanatında da görülür. Bu üslup 19. yüzyıl başlarına kadar devam etmiştir ${ }^{15}$.

17. yüzyılda çini süslemede saz üslubu iki yapıda görülür. Bunlardan biri konumuz olan Topkap1 Sarayı Bağdat Köşkü diğeri ise Kahire Aksungur Camii'dir. Topkap1 Sarayı Bağdat Köşkü'nde yer alan panolar, mekânda ocağın iki yanında vazodan çıkan iri saz yapraklar ve hatayilerdir. Bunlar arasında kuş figürleri de görülmektedir. Duvarlarda yer alan panolardan biri de kilinli panodur. Bu eser de saz üslubunun başarılı örneklerindendir. Vazodan çıkan saz yapraklı panoda yedi adet çini kullanılmıştır. 17. yüzyıl çinileri levha boyutları bazı istisnalar dışında genel olarak 25 x 25 $\mathrm{cm}^{\prime} \operatorname{dir}^{16}$. Bordür çinileri ise yarı ölçüdedir: $25 \times 12.5 \mathrm{~cm}$. Bunun dişında 17 . yüzyıl Sultan Ahmed Camii (1617) mahfil çinilerinden bir pano $25 \times 12.5 \mathrm{~cm}$ ebatlarında çinilerle oluşturulmuştur ${ }^{17}$. Topkapı Saray1 Bağdat Köşkü bordür çinilerinden Çin bulutlu hatayiler, helezon kuruluşlu kıvrık dallı hatayiler, saz üslubunda kilinli pano, saz üslubunda ayaklı vazodan çıkan hatayili süslemeli panoların dışında süsleme bordürlerle bir bütün olarak tasarlanmış levhalara aktarılmıştır. Bordür süslemeleri saz üslubunda ayaklı vazodan çıkan hatayi süslemeli pano hariç hepsi aynı süsleme kompozisyonunu içerir. Topkapı Sarayı Bağdat Köşkü’nde saz üslubundaki kilinli ve vazolu kuruluşlu panolar 32 x 49 ve 31 x $44 \mathrm{~cm}$ boyutlarında yedi çini levhanın üst üste konulmasıyla meydana gelmiştir. Bu süslemenin aynısı Kahire Aksungur Camii mihraplarında karşımıza çıkar. Burada da vazodan çıkan saz yapraklar süslemeyi oluşturmuştur. Bu panolar Topkapı Sarayı Sünnet Odası cephesinde yer alan 16. yüzyıl örneklerinin 17. yüzyılda yapılmış başarılı birer kopyasıdır. Söz konusu saz üslubundaki bu süslemeler İtalya da Roma Stroganoff Sarayı çinilerinde Osmanlı taklidi olarak görülür. Topkapı Sarayı Bağdat Köşkü’nde yer alan celi sülüs hatlı Ayetel Kürsi’yi, Tophaneli Enderuni Mahmud Çelebi'nin yazdığı bilinmektedir. Yazılı çini pano 25 x 37.5 ölçülerindeki çini levhalardan oluşur. 17. yüzyıl desenlerinde süsleme ölçeğinin büyüdüğ̈̈ görülmektedir. 17. yüzyıl çini yazı kuşakları 16. yüzyıl örneklerine göre daha iri boyutlarda yapılmışlardır. Bu durum bazen Topkapı Sarayı Bağdat Köşkü çinileri gibi çini ölçülerinin farklılı̆̆ına ya da 25 x 25 cm öl-

14 Walter B. Denny, "Dating Ottoman Turkish Works in the Saz Style," Muqarnas 1 (1983), 103.

15 Mahir, "Osmanlı Sanatında Saz Üslubundan Anlaşılan," 123-133; Banu Mahir, "Kanuni Döneminde Yaratılmış Yaygın Bezeme Üslubu; Saz Yolu," Türkiyemiz 54 (1988), 28.

16 Veronika Gervers-Molnar, "Turkish Tiles of the $17^{\text {th }}$ Century and Their Export," Fifth International Congress of Turkish Art (Budapeşte: Akademiai Kiado, 1978), 363.

17 Söz konusu çiniler 16. yy. depo çinileridir. Naza Dönmez, "Türk Çini Sanatının Sürekliliği İçinde XVII. Yüzyıl Eserlerinin Yeri,” 32. 
çülerindeki çinilerin üst üste 2-3-4 sıralı konulmasına göre değişmektedir ${ }^{18}$. Topkap1 Sarayı Bağdat Köşkü çinileri 17. yüzyıl Osmanlı çini sanatının teknik ve süsleme açısından en güzel uygulamalarının yer aldığı bir yapıdır. Çininin mimari ile birlikte tasarlanarak başarı ile mekâna uygulandığı bir yapı olarak da dikkat çekicidir. Çini yazı tasarımı başta olmak üzere, kemer iç yüzeyleri pandantifler ve mekân içindeki saz üslubundaki panolar bulundukları yere göre tasarlanmışlardır. Yapıdaki çiniler sır altı tekniğinde mavi-beyaz renklidir. Mavi beyaz renk, bu kadar yoğun çininin kullanıldığı yapıda bir ahenk ortaya koyarak huzurlu bir mekân ortaya çıkmıştır. Topkapı Sarayı Revan Köşkü, Topkapı Sarayı Bağdat Köşkü, Üsküdar Çinili Camii ve Yeni Camii ve Külliyesi’nde olduğu gibi 17. ikinci yarısında inşa edilmiş bütün mekânı kaplayan çinilerde de mavi beyaz renk tercih edilmiştir.

17. yüzyılda inşa edilen yapılara dayanarak bu dönemde yoğun bir çini faaliyetinin olduğu anlaşılmaktadır. 17. yüzyılda Avrupa'ya seramik ihracatı durmakla birlikte yoğun bir şekilde çini ihracı yapıldığı bilinmektedir. Avrupa'da Transilvanya Saropatlak Kalesi kazılarında Kırmızı Kule olarak tanınan yapıda bu çiniler kullanılmıştır. Ancak bu çiniler tipik 17. yüzyıl çinilerinden farklıdır ${ }^{19}$. Moldovya Suceava ve Iaşi'de yer alan kalelerde az sayıda çini parçası bulunmuştur. Ayrıca Yunanistan'da Athos Dağı manastırında 17. yüzyıl Türk çinileri kullanılmıştır. Athos Dağı manastırında yer alan İznik çinileri ayaklı kaseden çıkan natüralist çiçek süslemeli süpürgelik çini olarak kullanılan örneklerdir ${ }^{20}$. Yine bu dönemdeki yazışmalardan ortaya konan diğer bir yapı ise Kırım Han Sarayıdır. Sarayın çinileri de 17. yüzyıl Türk çinileridir ${ }^{21}$. Bunların hepsinin İznik üretimi olmadığı açıktır. Sultan Ahmed Camii inşaatından sonra İznik çini atölyelerinin çoğu işsiz kalmıştır. Evliya Çelebi Sultan I. Ahmed (1603-1617) zamanında üç yüzden fazla atölyeden bahsetmekle birlikte 1648 yılında İznik'te sadece dokuz atölyenin açık bulunduğunu söylemektedir ${ }^{22}$. Dolayısıyla yurt dışına yapılan ihracatlarda yurtiçinde olduğu gibi ikinci bir merkez olan Kütahya devreye girmiştir. Bazı örneklerde olduğu gibi her iki merkeze de benzemeyen çinilerin İstanbul atölyelerinde yapılmış olabileceği düşünülmektedir ${ }^{23}$.

18 Naza Dönmez, “Türk Çini Sanatının Sürekliliği İçinde XVII. Yüzyıl Eserlerinin Yeri,” 210-220.

19 17. yüzyıla ait mektup yazışmalarında ortaya konulan çini siparişi ile ilgili, Gervers-Molnar eserinde, İznik ve Kütahya dışı özellik gösteren bu çinilerin İstanbul atölyelerinde yapılmış olabileceğini belirtmiştir. Ayrıca çiniler tekstil karakterlidir. Daha önce de İstanbul atölyeleri hakkında bazı bilgiler mevcuttur. Ayrıca Evliya Çelebi de İstanbul atölyelerinden söz etmektedir. Bakınız Evliya Çelebi, Evliya Çelebi Seyahatnamesi (10 cilt), düzenleyen ve çeviren Tevfik Temelkuran ve Necati Aktaş (İstanbul: Tasvir Matbaası, 1986), I-II, 303; M Robert Mantran, 17. Yüzyılın İkinci Yarısında İstanbul. Kurumsal, Iktisadi, Toplumsal Tarih Denemesi, 2. cilt, çev. M.A. Kılıçbay ve E. Özcan (Ankara: Türk Tarih Kurumu, 1990), 11.

20 John Carswell, "Pottery and Tiles on Mount Athos," Ars Orientalis VI (1966), 77-90.

21 Julian, Raby, “1560-1650 İznik Seramiğinin Olgunluğu ve Bozulmas1,” İznik Seramikleri, ed. Nurhan Atasoy ve Julian Raby (London; Alexandria Press/Türk Ekonomi Bankası Yayınları, 1989), 279.

22 Evliya Çelebi, Evliya Çelebi Seyahatnamesi I-II, 758; Katharina Otto Dorn, Das Islamische İznik (Berlin: Selbstverlag des Archäologischen Instituts,1941), 192.

23 Kırımlı, "İstanbul Çiniciliği," 95-110. 
İznik, Osmanlı İmparatorluğunun çini ve seramik üretiminin yapıldığı merkezlerin başında yer alır. Ürettiği seramik kapları dünyaca ünlüdür. Ayrıca 17. yüzyıl Osmanlı yapılarını süsleyen çinilerin büyük bir çoğunluğunu İznik çinileri oluşturur. Kütahya Beylikler Dönemi’nden beri çini ve seramik merkezi durumundadır. Osmanlı Dönemi'nde İznik'ten sonra ikinci merkez Kütahya'dır. Özellikle 15. yüzyıl sonları ve 16. yüzyıl başlarında İznik ve Kütahya eşit koşullarda ve desenlerde üretim vermektedir. 16. yüzyıl İznik çinilerinin ön plana çıkması ile Kütahya geri planda kalmıştır. Kuşkusuz Kütahya bu dönemde de faaliyetlerini sürdürmüştür. 17. yüzyılda ise Kütahya'da üretimin İznik'ten daha fazla olduğu bilinmektedir ${ }^{24}$.

Sultan Ahmed Camii'nde Kütahya çinilerinin kullanıldığı çini panoları mevcuttur. Sultan Ahmet Camii'den sonra inşa edilen ve mavi-beyaz çinilerin yer aldığı Revan ve Bağdat Köşkleri, Üsküdar Çinili Camii, İstanbul Yeni Camii Külliyesi konu ile ilgili yabancı kaynaklarda İznik grubu içine dâhil edilmektedir ${ }^{25}$. Oktay Aslanapa Çinili Camii Kütahya olarak değerlendirmiştir ${ }^{26}$. Şerare Yetkin makalesinde yapıyı "İznik 17. yüzyıl çinilerini andıran bir üsluptadır”27 diyerek Kütahya çinileri olarak almıştır.

Gerçekten, Üsküdar Çinili Camii süslemeleri ile diğer Kütahya çini süslemeli yap1larından bariz bir şekilde ayrılmaktadır. Aynı zamanda yapı içinde yer alan süslemeli panolar, Bağdat Köşkü ve Yeni Cami panoları ile benzerdir. Özellikle yapının güney köşesinde yer alan pano süslemesi Yeni Cami Hünkar mahfili mihrabı üzerinde yer alan pano ile aynıdır. Yeni Camii çinilerinin İznik’te üretildiği bilinmektedir. ${ }^{28}$ Kronolojik sıralamaya bakıldığında da arada kalan Üsküdar Çinili Camii, çinilerinin de büyük bir kısmı İznik olmalıdır. Ayrıca Gönül Öney detaylı açıklama yapmadan yapının çinilerinin İznik ve Kütahya olduğunu belirtmektedir ${ }^{29}$. Süsleme desenleri göz önünde bulundurulduğunda kadınlar mahfili ve son cemaat yerinde bulunan kıvrık dallı hatayili çini levhalar Kütahya'da yapılmış olmalıdır. Aynı çini levhalar Revan ve Bağdat köşklerinde yer alır. Dolayısı bu yapıları süsleyen bir kısım çini de Kütahya olmalıdır. Hatta Yeni Cami çinilerinin bir kısmı da bu grubun içinde Kütahya çinisi olabilir. Söz konusu durum Topkapı Sarayı Harem çinileri için de geçerlidir ${ }^{30}$. Harem çini tasarımı-

24 Carswell "Pottery and Tiles on Mount Athos," 53

25 Viktoria Meinecke Berg, "Marmorfliesen zum Verhaeltnis von Fliesendekoration und Architektur in der Osmanischen Baukunst," Kunst der Orients VIII/2 (1972), 52; John Carswell ve Charles James Frank Dowsett, Kütahya Tiles and Pottery from the Armenian Cathedral of St. James, Jerusalem, 2. cilt (Oxford: Clarendon Press, 1972), 10; Raby, "1560-1650 İznik Seramiğinin Olgunluğu ve Bozulması," 278.

26 Oktay Aslanapa, Osmanlı Devrinde Kütahya Çinileri (İstanbul: İstanbul Üniversitesi Edebiyat Fakültesi Yayınları, 1949), 105.

27 Şerare, Yetkin "Kütahya Dışındaki Kütahya Çinileri ile Süslü Eserler," Kütahya. Atatürk'ün Doğumunun 100. Yllına Armağan (İstanbul: İstanbul Üniversitesi Edebiyat Fakültesi Yayınları, 1982), 85.

28 Yeni Camii yazılarının hattatı Teknecizade İbrahim'in bunun için İznik'e gittiği Tufe-i Hattatin'de yer alır. Müstakimzade Süleyman Saadeddin Efendi, Tuhfe-i Hattatin, 48; İstanbul Yeni Cami ve Hünkar Kasrı Vakıflar Genel Müdürlüğ̈̈ Yayını, 23.

29 Gönül Öney, Türk Çini Sanatı/Turkish Tile Art (İstanbul: Yapı Kredi Yayınları, 1976), 92.

30 Topkapı Sarayı Harem çinileri için bk. Demirsar Arlı ve Altun, Anadolu Toprağının Hazinesi Çini Osmanlı Dönemi, 123; Ahmet Vefa Çobanoğlu, “Topkapı Sarayı'nda Çini,” İstanbul'un Renkli Hazineleri Bizans 
nı çalışan Zehra Dumlupınar Harem çinilerinin İznik’e sipariş edildiğini gösteren bir arşiv belgesi ortaya çıkarmıştır ${ }^{31}$. Ancak yine de bu kadar yoğun çini kaplı olan Harem çinilerini Sadece İznik olarak yorumlamak yukarıda yapılan açıklamalar göz önünde bulundurulduğunda mümkün görülmemektedir. 17. yüzyıl Kütahya çinilerinin hangi yapılarda kullanılmış olduğuna dair kesin bir bilgi elimizde mevcut değildir.

\section{Sonuç}

Topkapı Sarayı Bağdat köşkü çini süslemeleri 17. yüzyılın en başarılı örneklerindendir. Mekânda çinilerin saz üslubu desenleri, 16. yüzyılda Nakkaş Şahkulu'nun desenleri ile ortaya çıkmıştır. Bu üsluptaki aynı çini süslemeleri Topkapı Sarayı Sünnet Odası cephesinde ve Kahire Aksungur Camii iç mekânda görülür. İtalya Roma Stroganoff Sarayı'ndaki ocakta yer alan aynı süslemeli İtalyan çinileri ise Osmanlı etkisini yansıtması açısından ilgi çekicidir. Çini üretiminin çok yoğun yaşandığı 17. yüzyılda Kütahya ve İznik atölyeleri birlikte üretim yapmaya devam etmiştir. Başta Topkapı Sarayı Haremi olmakla birlikte çini dekorasyonun kullanıldığı Sultan Ahmet Camii, Üsküdar Çinili Camii ve Yeni Camii' de de İznik ve Kütahya çinileri bir arada kullanılmıştır ${ }^{32}$. Söz konusu yapıların çinilerinin üretim yerlerini sınırlı sayıdaki arşiv kaynakları dışında, boyut ve desen seçiminden kısmen ayırt edebilmek mümkündür. Topkapı Sarayı Bağdat Köşkü dış cephe çinileri boyut ve desenleri anlamında Kütahya üretimi gibi durmaktadır. İç mekân çinileri ise aynı sebebe dayanarak İznik üretimi olduğu düşünülmektedir.

\footnotetext{
Hakem Değerlendirmesi: Dış bağımsız.

Çıkar Çatışması: Yazar çıkar çatışması bildirmemiştir.

Finansal Destek: Yazar bu çalışma için finansal destek almadığını beyan etmiştir.

Teşekkür: Söz konusu yazının hazırlanmasında yardımlarından dolayı Arkeolog Burçin Adısönmez ve Gökçe Özbek’e teşekkür ederim.

Peer-review: Externally peer-reviewed.

Conflict of Interest: The author has no conflict of interest to declare.

Grant Support: The author declared that this study has received no financial support.

Acknowledgement: I would like to thank Archaeologist Burçin Adısönmez and Gökçe Özbek for their assistance in preparing the article in question.
}

Mozaiklerinden Osmanlı Çinilerine (İstanbul: İstanbul Ticaret Odası Yayınları, 2011), 254-295; E. Emine Naza Dönmez, “Topkapı Sarayı'nda 17. Yüzyıla Ait Usta Kitabeli Çiniler,” İstanbul Araştırmaları Yıllı̆̆l Annual of İstanbul Studies 4 (2015), 89-99; F. Zehra Dumlupınar, “Topkapı Sarayı Harem Dairesi 17. Yüzyıl Çini Pano Tasarımları” (Doktora Tezi, Marmara Üniversitesi, 2015), E. Emine Naza Dönmez, “Topkap1 Sarayı Harem Şadırvanlı Sofa Daire Madalyonlu Çini Yazıları," Arkeoloji, Tarih ve Epigrafi'nin Arasında Prof. Dr. A. Vedat Çelgin'in 68. Doğum Günü Onuruna Makaleler (İstanbul: Arkeoloji ve Sanat Yayınları, 2018), 66-99.

31 17. yüzyıl harem çinileri için Osmanlı Arşivi'nde kayıtlı bulunan defterde harem dairesi yangınından sonra İznik'e çini sipariş verildiği yazılmıştır. Söz konusu defter H.1076 tarihli olup Başbakanlık Arşivi, Maliyeden Müdevver Defterler 908'e kayıtlıdır. Bk. Dumlupınar, “Topkapı Sarayı Harem Dairesi 17. Yüzyıl Çini Pano Tasarımları," 487.572. 607, Ek. 1-2, 591-592.

32 Naza Dönmez, “Türk Çini Sanatının Sürekliliği İçinde XVII. Yüzyıl Eserlerinin Yeri,” 9. 


\section{Kaynakça/References}

Aslanapa, Oktay. Osmanlı Devrinde Kütahya Çinileri. İstanbul: İstanbul Üniversitesi Edebiyat Fakültesi Yayınları, 1949.

Bakır, S. Turan. İznik Çinileri ve Gülbenkyan Kolleksiyonu. Ankara: Kültür Bakanlığı Yayınları, 1999.

Bayrak, Muharrem Orhan. Topkapı Sarayı. İstanbul: Sümer Kitapevi Yayınları, 1996.

Birol, İnci ve Çiçek Derman. Türk Tezyini Sanatlarında Motifler. İstanbul: Kubbealtı Yayınevi, 1991.

Carswell, John. "Pottery and Tiles on Mount Athos." Ars Orientalis VI (1966): 77-90.

Carshwell, John ve Charles James Frank Dowsett. Kütahya Tiles and Pottery from the Armenian Cathedral of St. James, Jerusalem. 2. cilt. Oxford: Clarendon Press, 1972.

Çobanoğlu, A. Vefa. “Topkap1 Sarayı'nda Çini,” İstanbul'un Renkli Hazineleri Bizans Mozaiklerinden Osmanlı Çinilerine. İstanbul: İstanbul Ticaret Odası Yayınları, 2011, 254-295.

Demirsar Arlı, Belgin ve Ara Altun. Anadolu Toprağının Hazinesi Çini Osmanlı Dönemi. İstanbul: Kale Grubu Kültür Yayınları, 2008.

Denny, Walter B. "Dating Ottoman Turkish Works in the Saz Style." Muqarnas 1 (1983): 103-121.

Dumlupınar, F. Zehra. “Topkapı Sarayı Harem Dairesi 17. Yüzyıl Çini Pano Tasarımları.” Doktora Tezi, Marmara Üniversitesi, 2015.

Eldem, Sedat Hakk1. Köşkler ve Kasırlar 1. İstanbul: Devlet Güzel Sanatlar Akademisi, 1968.

Eldem, Sedat Hakkı ve Ferudun Akkozan. Topkapı Sarayı. İstanbul: Kültür ve Turizm Bakanlığı Yayınları, 1982.

Erdmann, Kurt. "Die Fliesen am Sünnet Odasi des Top Kap1 Saray in İstanbul.” Aus der Welt Der Islamischen Kunst Festschrift für Ernst Kühnel. Berlin: Verlag Gebr. Mann, 1959, 144-153.

Esemenli, Deniz. "Mekanlar-Zamanlar.” Topkapı Sarayı. İstanbul: Akbank Yayınları, 2000, 24-135.

Evliya Çelebi. Evliya Çelebi Seyahatnamesi (10 cilt). Düzenleyen ve Çeviren Tevfik Temelkuran ve Necati Aktaş. İstanbul: Tasvir Matbaası, 1986.

Eyice, Semavi. “Bağdat Köşkü.” Dünden Bugüne İstanbul Ansiklopedisi. 1. İstanbul: Tarih Vakfi, 1993, 531-532.

Eyice, Semavi. "Kasım Ağa.” TDV İslam Ansiklopedisi. 24. İstanbul: Türkiye Diyanet Vakfı Yayınlar1, 2001, 539-540.

Fontana, Maria Vittoria. "İmitations of İznik Ceramics Produced by the Neapolitan Delle Donne Factory for the Stroganof Palace in Rome," First International Congress on Turkish Tiles and Ceramics (6-11.VII.1986 - Kütahya). İstanbul: Türk Petrol Vakf1, 1989, 119-142.

Gervers-Molnar, Veronika. "Turkish Tiles of the $17^{\text {th }}$ Century and Their Export," Fifth International Congress of Turkish Art. Budapeşte: Akademiai Kiado, 1978, 363-384.

İstanbul Yeni Camii ve Hünkar Kasrı. Vakıflar Genel Müdürlüğü Yayınları.

Koçer Yeşilyurt, Funda. “Topkapı Sarayı Dördüncü Avludaki Yapılarda Kullanılan Çiniler.” Doktora Tezi, Atatürk Üniversitesi, 2014.

Koçu, Reşat Ekrem. “Bağdat Köşkü.” İstanbul Ansiklopedisi. IV. İstanbul: Tan Matbaas1, 1960, 1804-1808.

Kırımlı, Faik. “İstanbul Çiniciliği.” Sanat Tarihi Yıllı̆̆̆ XI (1981): 95-110. 
Mahir, Banu. "Osmanlı Sanatında Saz Üslubundan Anlaşılan.” Topkapı Sarayı Müzesi Yıllık 2 (1987): 123-140.

Mahir, Banu. "Kanuni Döneminde Yaratılmış Yaygın Bezeme Üslubu; Saz Yolu.” Türkiyemiz 54 (1988): 28-37.

Mantran, M. Robert. 17. Yüzyılın İkinci Yarısında İstanbul. Kurumsal, İktisadi, Toplumsal Tarih Denemesi. II. cilt. Çev. M.A. K1lıçbay ve E. Özcan. Ankara: Türk Tarih Kurumu, 1990.

Meinecke Berg, Viktoria. "Marmorfliesen zum Verhaeltnis von Fliesendekoration und Architektur in der Osmanischen Baukunst." Kunst der Orients VIII/2 (1972): 35-39.

Müstakimzade Süleyman Saadeddin Efendi. Tuhfe-i Hattatin. Nşr. Mahmud Kemâl İnal. İstanbul: Devlet Matbaası, 1928.

Nayır, Zeynep. Osmanlı Mimarlı̆̆ında Sultan Ahmet Külliyesi ve Sonrası (1609-1690). İstanbul: İTÜ Mimarlık Fakültesi, 1975.

Naza Dönmez, E. Emine. "Türk Çini Sanatının Sürekliliği İçinde XVII. Yüzyıl Eserlerinin Yeri.” Doktora tezi, İstanbul Üniversitesi, 2001.

Naza Dönmez, E. Emine. "Osmanlı Dönemi Türk Çini Sanatı (Erken, Klasik, Geç Devirler)," Türkler Ansiklopedisi. 12. Cilt. Ankara: Yeni Türkiye Yayınları, 2002, 366-375.

Naza Dönmez, E. Emine. “Topkapı Sarayı’nda 17. Yüzyıla Ait Usta Kitabeli Çiniler.” Ístanbul Araştırmaları Yıllı̆̆ / Annual of İstanbul Studies 4 (2015): 89-99.

Naza Dönmez, E. Emine. “Topkapı Sarayı Harem Şadırvanlı Sofa Daire Madalyonlu Çini Yazıları," Arkeoloji, Tarih ve Epigrafi'nin Arasında Prof. Dr. A. Vedat Çelgin 'in 68. Doğum Günü Onuruna Makaleler. İstanbul: Arkeoloji ve Sanat Yayınları, 2018, 66-99.

Necipoğlu, Gülru. "From International Timurid to Ottoman: A Change of Taste in Sixteenth-Century Ceramic Tiles." Muqarnas 7 (1990): 136-170.

Yamanlar, M. Mizuno. "Hatayi Motifinin Menşei," 9. Milletlerarası Türk Sanatları Kongresi. III. cilt. Ankara: Kültür Bakanlığı, 1995, 445-448.

Otto Dorn, Katharina. Das Islamische İznik. Berlin: Selbstverlag des Archäologischen Instituts, 1941.

Ortaylı, İlber. Mekanlar ve Olayları ile Topkapı Sarayı. İstanbul: Bank Asya Kültür Yayınları, 2007. Öney, Gönül. Türk Çini Sanatı/Turkish Tile Art. İstanbul: Yapı Kredi Yayınları, 1976.

Porter, Venetia. Islamic Tiles. London: The British Museum Press, 2008.

Raby, Julian. “1560-1650 İznik Seramiğinin Olgunluğu ve Bozulması.” İznik Seramikleri. Ed. Nurhan Atasoy ve Julian Raby. London; Alexandria Press/Türk Ekonomi Bankası Yayınları, 1989, 218-288.

Yetkin, Şerare. "Kütahya Dışındaki Kütahya Çinileri ile Süslü Eserler.” Kütahya. Atatürk'ün Doğumunun 100. Yılına Armağan. İstanbul: İstanbul Üniversitesi Edebiyat Fakültesi Yayınları, 1982, 83-110. 
